determined by the chelate formation with pentacyanoaquaferroate (6). p-Aminobenzoic acid (ABA) was determined by the method of Fouts and Brodie (1).

Table 1 shows that NADPH-linked reduction of $p$-nitrobenzoic acid to $p$-hydroxyaminobenzoic acid is mainly localized in microsomes, whereas NADH-linked nitroreduction is localized in supernatant. The activity of NADPH- and NADH-linked nitroreduction is almost same in supernatant. Moreover, the reduction of $p$-hydroxyaminobenzoic acid is done in both microsomes and supernatant, but the activity is higher in microsomes than that in supernatant.

The NADPH-linked activity is about $50_{\%}^{\circ}$ higher than the NADH-linked activity in microsomes. Thus, the NADH-linked reduction of $p$-nitrobenzoic acid to $p$-aminobenzoic acid is negligible in microsomes, but the NADH-linked reduction in microsomes + supernatant is about $30 \%$ of the NADPH-linked activity in accord with results of Fouts and Brodie (1). These results suggested that the first step of the NADH-linked reduction of $p$-nitrobenzoic acid to $p$-aminobenzoic acid is mainly done by supernatant and the second step is mainly mediated by microsomes. The NADPH-linked reduction of $p$-nitrobenzoic acid to $p$-hydroxyaminobenzoic acid is the important step for all over nitroreduction and this step is likely the rate limiting step.

In further experiments it was shown that the NADPH-linked reduction of $p$-nitrobenzoic acid to $p$ hydroxyaminobenzoir arid was inhibited by oxygen and stimulated by FMN or FAD and the microsomal activity was stimulated by phenobarbital. The NADPH-linked nitroreductase of microsomal fraction likely differed from that of supernatant, because the former was stimulated by phenobarbital and inhibited by oxygen, whereas the later was not stimulated by phenobarbital and only partially inhibited by oxygen. The detailed results will be published elsewhere (7).

\title{
REFERENC'ES
}

1) Fouts, J.R. and Bronil, B.B.: J. Pharmac. exp. Ther. 119, 197 (1957); 2) КАмm, J.J. And Giflift'te, J.R.: Life Sci. 2, 259 (1963); 3) Hart, L.G., Adamson, R.H., Dixon, R.I. and Fouts, J.R.: J. Pharmac. exp. Ther. 137, 103 (1962); 4) Kato, R. and Takahashi, A.: Mol. Pharmac. 4, lo9 (1968); 5) Baver, H. and Rosevtral, S.M.: J. Chem. Soc. 6, 611 (1944); 6) Feigle, F.: Spot Test in Organic Analysis, Vol. 2, p. 121, Elsevier Pub. Comp., Amsterdam (1954); 7) Kato, R., Oshrma, T. AND TAKANAKA, $A .:$ in preparation

\section{ANTITREMOR ACTION OF A NEW BETA RECEPTOR BLOGKING AGENT (I.C.I. 50, 172)}

\author{
G. ACHARI AND S.P. SINHA \\ Department of Pharmacology, P. W. Medical College, Patna-4, India
}

Received for publication June 18, 1968

In a previous communication (1) it was reported that propranolol (Inderal) a beta receptor blocking agent abolishes tremor induced by tremorine. A number of structurally similar adrenergic beta receptor blocking agents have been synthesized recently and their actions are almost similar qualitatively in that they all block beta receptor but they differ quantitatively. A new beta receptor blocking agent (I.C.I.50, 172), which does not block all the receptors (2) have been studied in rats to find out the action if tremorine (1,4-dipyrdino2-butyne) induced tremor and its cholinergic effects are blocked by this new beta receptor blocking agent I.C.I. $50,172$.

Methods: Experiments were carried out in albino rats (C.D.R.I., Strain) of both sexes weighing between 
TabLE 1. Effect of I.C.I. 50, 172 in tremorine induced tremor in albino rats.

\begin{tabular}{cccccc}
\hline Groups & $\begin{array}{c}\text { Dose } \\
\mathrm{mg} / \mathrm{kg}\end{array}$ & $\begin{array}{c}\text { No. of animals } \\
\text { pretreated } \\
\text { No. of animals } \\
\text { protected }\end{array}$ & $\%$ protection & $\begin{array}{c}\text { Occurence of } \\
\text { diarrhoea and } \\
\text { salivation }\end{array}$ & $\begin{array}{c}\text { Abnormal } \\
\text { behaviour }\end{array}$ \\
\hline 1 & 0.5 & $10 / 0$ & $0 \%$ & profuse & Nil \\
2 & 1.0 & $10 / 2$ & $20 \%$ & moderate & Nil \\
3 & 2.0 & $10 / 3$ & $30 \%$ & slight & Nil \\
4 & 4.0 & $10 / 6$ & $60 \%$ & absent & Nil \\
5 & 6.0 & $10 / 8$ & $80 \%$ & absent & Nil \\
6 & 8.0 & $10 / 9$ & $90 \%$ & absent & Nil \\
\hline
\end{tabular}

TABLE 2. Comparison of antitremorine potency of atropine and the new compound I.C.I. 50, 172 .

\begin{tabular}{ccc}
\hline Drugs & $\mathrm{ED}_{50} \mathrm{mg} / \mathrm{kg}$ with S.E. & Potency ratio \\
Atropine sulphate & $1.30-0.291$ & 1 \\
I.C.I. 50,172 & $3.05-0.554$ & 0.426 \\
\hline
\end{tabular}

$100-150 \mathrm{~g}$ at room temperature (average of $36 \mathrm{C}$ ). The concentration of the compound was such that the required dose could be given in volume of $0.5 \mathrm{ml} / 100 \mathrm{~g}$ of body weight. Croups of ten animals were pretreated subcutaneously with the test drug prior to the test. Fifteen $\mathrm{mg} / \mathrm{kg}$ of tremorine was given intraperitoneally 20 minutes before the test. The antitremor effect was measured by Rota-Rod test (3). The median effective dose $\left(\mathrm{ED}_{5,0}\right)$ was calculated by the method of Miller and Tainter (4). The incidence of diarrhoca and salivary secretion was noted.

Results: Six groups of animals were pretreated with various doses e.g. 0.5, 1.0, 2.0, 4.0, 6.0 and 8.0 $\mathrm{mg} / \mathrm{kg}$. Twenty", protection was obtained with $1.0 \mathrm{mg} / \mathrm{kg}$, whereas with $8 \mathrm{mg} / \mathrm{kg} 90 \%$ protection was seen. The results are summarized in Table 1.

The results from Table 1 indicate that the effect of I.C.I. 50, 172 on tremorine induced tremor is dosedependent. The incidence of salivary secretion and diarrhoea (cholinergic effects) was present up to dose of $2 \mathrm{mg} / \mathrm{kg}$. With the increase of dose up $104 \mathrm{mg} / \mathrm{kg}$ the diarrhoea and salivation was absent. The animals

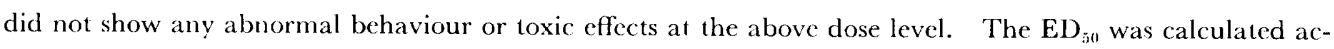
cording to the method of Miller and Tainter (4). The calculated $\mathrm{ED}_{50}$ was $3.05 \pm 0.554 \mathrm{mg} / \mathrm{kg}$. The potency of I.C.I. 50, 172 was compared with atropine and is shown in Table 2.

Discussion and conclusion: The present study revealed that the new beta adrenergic blocking agent (I.C.I. $50,172)$ not only blocked the tremorine induced tremor but also the incidence of salivation and diarrhoea, while Inderal (propranolol) gave $90 \%$ protection at a dose level of $4 \mathrm{mg} / \mathrm{kg}$ but the salivation and diarrhoea was not abolished. The effect of Inderal and the I.C.I. 50, 172 on the abolition of tremorine induced tremor perhaps gives further evidence to the theory that catecholamines have some role in the causation of both tremorine induced tremor and Parkinson's disease. Further work is necessary to elucidate the mechanism of blockage of salivation and diarrhoea by this new compound I.C.I. 50, 172.

Acknowledgement: The authors are thankful to Dr. Desmond Fitzerald of I.C.I. for supplying us a frec sample of I.C.I. 50, 172 and Shri Ramdahin Prasad for helping us in carrying out this work.

\section{REFERENCES}

1) Achari, G. and Sinha, S.P.: This Journal 17, 680 (1967); 2) Dunlop, D. and Shanks, R.G.: Br. J. Pharmac. Chemother. 32, 201 (1968); 3) Stone, C.A.: Personal communication (1960); 4) MirLer, L.C. And Tainter, M.L..: Proc. Soc. exp. Biol. Med. 57, 261 (1944) 